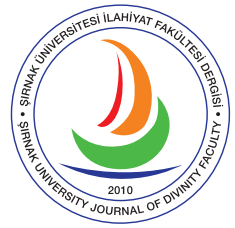

\title{
İlahiyat Alanında Pedagojik Formasyon Eğitimi Alan Öğretmen Adaylarının Gözüyle Din Dersi Öğretmenleri
}

Teachers of Religious Education Course Through the Eyes of the Teacher Candidates Training Pedagogical Formation Education in the Field of Theology

\section{Ayșegül Gün}

Dr. Öğr. Üyesi, Amasya Üniversitesi, İlahiyat Fakültesi, Din Bilimleri Ana Bilim Dalı Assistant Professor, Amasya University, Faculty of Divinity, Department of Science of Religion Amasya, Turkey aysegul.gun@amasya.edu.tr https://orcid.org/0000-0001-6321-0644

\section{Makale Bilgisi / Article Information}

Makale Türü / Article Types: Araştırma Makalesi / Research Article

Geliş Tarihi / Received: 12 Şubat / February 2020

Kabul Tarihi / Accepted: 13 Mart / March 2020

Yayın Tarihi / Published: 15 Haziran / June 2020

Cilt / Volume: 11 Sayı / Issue: 24 Sayfa / Pages: 129-158

Atıf / Cite as: Gün, Ayşegül. "İlahiyat Alanında Pedagojik Formasyon Eğitimi Alan Öğretmen Adaylarının Gözüyle Din Dersi Öğretmenleri [Teachers of Religious Education Course Through the Eyes of the Teacher Candidates Training Pedagogical Formation Education in the Field of Theology]". Şırnak Üniversitesi İlahiyat Fakültesi Dergisi-Şırnak University Journal of Divinity Faculty 11/24 (June 2020), 129-158. https://doi.org/10.35415/sirnakifd.688362

Etik Beyanı / Ethics Declaration: Bu makalede bilimsel araştırma ve yayın etiği ilkelerine riayet edilmiştir. Makale en az iki hakem tarafından incelenmiş ve intihal içermediği teyit edilmiştir./ In this article, the principles of scientific research and publication ethics are respected. It has been reviewed by at least two referees and was confirmed that it did not contain plagiarism.

Copyright (C Published by Şırnak Üniversitesi, İlahiyat Fakültesi / Şırnak, Türkiye (Şırnak University, Faculty of Divinity, Şırnak, 73000 Turkey). 


\title{
Öz
}

Pedagojik formasyon eğitimi alan öğretmen adaylarının uygulama öğretmenlerine dair değerlendirmeleri, uygulama derslerinin verimliliği bakımından bize fikir verebilecek türdendir. Bu araştırma kapsamında da Amasya Üniversitesinde İlahiyat alanında pedagojik formasyon eğitimi alan öğretmen adaylarının, örgün eğitimde görev yapan din dersi öğretmenlerinin mesleki yeterlikleriyle ilgili algıları ve uygulama öğretmenleri rehberliğindeki bu uygulamadan ne kadar istifade edebildikleri öğrenilmeye çalışılmıştır. Tarama yönteminin kullanıldığı araştırmada, araştırmacı tarafından geliştirilmiş olan anket formu, öğretmenlik uygulaması yapmış olan pedagojik formasyon öğrencilerine yüz yüze eğitim aldıkları sırada uygulanmış, dağıtılan 395 anketten 332'si değerlendirmeye alınabilmiştir. Sonuçta, öğretmen adaylarının din dersi öğretmenlerini alan bilgisi ve öğrencilerle iletişim konusunda büyük oranda yeterli gördükleri, ancak derse hazırlıklı gelme bakımından önemli bir kısmını yetersiz buldukları tespit edilmiştir. Ayrıca, öğrenciyi aktif hale getirmeye ve kalıcı öğrenmeler sağlamaya önemli katkısı olan birçok öğretim yöntem ve tekniği olmasına rağmen din dersi öğretmenlerinin büyük bir bölümü genellikle anlatım, soru-cevap ve tartışma yöntemleriyle dersi işlemeye devam etmektedir. $\mathrm{Bu}$ düşünceler 1şığında, öğretmen adayları genel itibariyle öğretmenlik uygulamasını faydalı bulmakla birlikte uygulama öğretmeninden kaynaklanan sebeplerden dolayı hiç istifade edemediğini belirtenler de vardır.

Anahtar Kelimeler: Din Eğitimi, Mesleki Yeterlilik, Uygulama Öğretmeni, Öğretmen Adayı, Öğretmenlik Uygulaması.

\begin{abstract}
The evaluations of teacher candidates who have received pedagogical formation training about practice teachers are in a kind that can give us an idea in many aspects. Within the scope of this research, it was tried to learn the teacher candidates' perceptions who receive pedagogical formation education in the field of theology in the Amasya University, about the professional competencies of religious education teachers working in formal education and how they could benefit from this application under the guidance of practice teachers. In the research using the survey method, the questionnaire form developed by the researcher was applied to pedagogical formation students who had been receiving face-to-face education. 332 of the 395 questionnaires distributed were evaluated. As a result, it was determined that teacher candidates perceived religious lesson teachers largely sufficient in terms of field information and communication with students, but they found a significant part of them to be inadequate in terms of preparing for the lessons. In addition, although there are many teaching methods and techniques that make a significant contribution to activating the student and providing permanent learning, most of the religious education teachers continue to teach the lessons with narrative, question and answer and discussion methods. In the consideration of these thoughts teacher candidates find the teaching practice useful in general, there are also those who state that they could not benefit from the application for the reasons caused by practice teachers.
\end{abstract}

Keywords: Religious Education, Professional Competence, Practice Teacher, Teacher Candidates, Teaching Practice. 


\section{Extended Abstract}

The aim of the teaching practice carried out in formal education institutions affiliated to the Ministry of National Education is to provide the opportunity to use the knowledge, skills and attitudes they have acquired during their undergraduate education in the learning environment. One of the guides in this process is the practice teachers in schools. Being a good role model of practice teachers will increase the motivation of candidate teachers by affecting this preparation process positively.

In our country, some criteria have been determined for teachers to fulfill their duties successfully. These are general competencies that all teachers should have and special field competencies that are defined separately for each branch teacher. Among the general competencies, there are three different proficiency scale consisting of professional knowledge, professional skills, attitudes and values. Among the special field competencies that should be in the teachers of Religious Culture and Moral Knowledge course are to be able to use methods, technical and technological facilities suitable for the content of the course and to guide the student to recognize the phenomenon of religion.

Within the scope of the research, the perceptions of teacher candidates about the professional competencies of religious education teachers working in formal education institutions and how much did they benefit from this practice guided by practice teachers were questioned. The universe of the study carried out for this purpose is the teacher candidates who pedagogical formation education in the field of theology in the Amasya University.

In this descriptive study, data were obtained through a questionnaire prepared by the researcher. 332 questionnaires that were returned from the questionnaires distributed during the pedagogical formation education face-to-face course application were evaluated. The personal information of the respondents are as follows: $98(29.5 \%)$ of the them are male and $234(70.5 \%)$ are female. $260(78.3 \%)$ of the respondents graduated from Imam Hatip High School and 72 (21.7\%) of them graduated from other high schools. 4 (1.2\%) graduated from theology faculty (formal education), $305(91.9 \%)$ are senior students of theology faculty, 11 (3.3\%) graduated from İLITAM, 11 (3\%) are senior students of İLİTAM.

The teacher candidates were asked to evaluate the practice teachers in terms of field knowledge. $34.7 \%$ of the respondents who answered this question stated that the field knowledge of the practice teachers was "very 
good", $49.8 \%$ stated that it was "good", $13.9 \%$ stated that it was "medium" and $1.5 \%$ stated that it was "insufficient". When we look at the studies in which the teachers of religious education course evaluate themselves, it is seen that there is a similar result. Another question is about the communication of religious education teachers with students. $34.1 \%$ of teacher candidates stated that their practice teacher's communication with their students was "very good", $45.9 \%$ stated that it was "good", $13.9 \%$ stated that it was "moderate" and $6 \%$ stated that it was "inadequate". When the researches were compared, it was observed that there was a partial difference between the students 'perceptions and teachers' self-perceptions. When practice teachers are evaluated in terms of classroom management skills, $33.5 \%$ of the respondents stated that their practice teacher was "very good", $42 \%$ stated that it was "good", 20.2\% stated that it was "moderate" and $4.2 \%$ stated that it was "inadequate". This result match up with other research results.

The findings of the other questions can be summarized as follows: The rate of those who stated that the practice teacher made preparations for each course was $51.7 \%$, the rate of those who stated that they made preparations from time to time was $37.7 \%$ and the rate of those who stated that they teach the course without making preparations $10.6 \%$; the rate of those who stated that the practice teacher loved his job is $83.1 \%$. The religious education teachers use "Narrative", "Question-answer" and "Discussion" teaching methods respectively. According to the teacher candidates, religious education teachers usually continue to teach the lessons with traditional methods.

In the light of their evaluations, teacher candidates were asked if they found this practice useful for them. $75.7 \%$ of those who answered this question stated that they found it useful, $22.5 \%$ partially found it useful, and $1.8 \%$ did not find it useful. The positive respondents stated that this is a good experience and that they can see their shortcomings and partially defeat their excitement. In the formation of these positive thoughts, the effectiveness of the practice teachers can be seen in the answers. The teacher candidates, who had a negative opinion about the practice, linked this to the apathy or inadequacy of the practice teacher, the attitudes of the headmaster and teachers at the practice school. 


\section{GİRIŞ}

Pedagojik formasyon programı, Eğitim Fakültesi dışındaki fakültelerde öğrenim gören ya da bu fakültelerden mezun olanların öğretmen olarak atanabilmeleri için, eğitim fakülteleri bünyesinde mesleğe yönelik eğitim-öğretim görerek sertifika almaya hak kazandıkları bir eğitim programıdır. ${ }^{1}$ Başladığı günden bu yana eğitim süresi ve uygulamaya dönük birtakım değişimler geçiren programın son dönemdeki uygulaması ise iki dönemlik bir süreç içerisinde öngörülen eğitimin verilmesi ile gerçekleştirilmektedir. Bu eğitim programında yer alan derslerden biri de öğretmenlik uygulaması olup bu sayede öğrenciler, öğretmenlik mesleğine dair edindiği bilgi ve becerileri kullanma imkanını elde ettikleri bir staj tecrübesi yaşamaktadırlar. ${ }^{2}$

Okullarda gerçekleştirilen öğretmenlik uygulamasında amaç, öğrencilerin öğretmenlik mesleğine daha iyi hazırlanmalarını sağlamak ve eğitimleri süresince edindikleri bilgi, beceri ve tutumları öğrenme ortamı içinde kullanma yeterliğini kazandırmaktır. Bu sürecin başarılı bir şekilde geçirilebilmesi için kurum koordinatörleri, uygulama öğretim elemanı ve uygulama öğretmenleri, iş birliği içerisinde görevlerini yerine getirmektedir.

Okullarda gerçekleştirilen öğretmenlik uygulamasının önemli paydaşlarından biri, uygulama öğretmenleridir. Uygulama öğretmeni, uygulama

1 YÖK, 2017 yılında almış olduğu bir kararla, pedagojik formasyon eğitiminin ilahiyat fakültelerindeki lisans programına dahil edilmesine ve 2017-2018 eğitim-öğretim yılından itibaren yeni lisans programının uygulanmasına karar vermiştir (Yüksek Öğretim Kurulunun dağıtım yerlerine göndermiş olduğu "İlahiyat Formasyon Programları" başlıklı, 23/06/2017 tarih ve 75850160-104.01.07.01-43446 sayılı yazı.)

2 Murat Tuncer - Hasan Güner Berkant, "Öğretmen Yetiştirme Programlarının Özellikleri", Öğretmen Yetiştirme Sistemimiz, ed. Mustafa Ergün vd. (Ankara: Pegem Akademi, 2018), 113-118. 
öğrencisine, öğretmenlik mesleğinin gerektirdiği öğretmenlik uygulamaları hakkında rehberlik edecek kişidir. Bu süreçte uygulama öğretmeninin görevi, uygulama öğrencilerinin hazırladıkları etkinliklerle ilgili öneride bulunmak, bu etkinlikleri başarılı bir biçimde yerine getirmesi konusunda uygulama öğrencisine rehberlik etmek ve onu değerlendirmektir. ${ }^{3}$ Bunun dişında kalan zamanlarda öğrenciler, uygulama öğretmenini ve eğitim öğretim faaliyetlerini gözlemlemektedir. Bu gözlemler, öğrencinin kendisini geliştirebilmesi için önemli olduğu kadar, öğretmenlerin değerlendirilebilmesi açısından da bir fırsat sunmaktadır.

Gerek klasik dönem İslam eğitim tarihinde gerekse günümüz modern eğitim anlayışında, öğretmenlerin tüm yeterlik alanlarında yetkin olmasının önemine değinilmiş ve eğitim sistemi bu bakış açısıyla şekillendirilmiştir. Klasik dönemden itibaren, öğretmenliğin bir sanat olduğu, bazı insanların bu konuda doğuştan kabiliyetli olmasına rağmen yine de bazı mesleki özellikleri taşımasının önemi ve bu konuda bir hocanın gerekliliği kabul edilmiştir. ${ }^{4}$ Buna göre öğretmen, mesleğinde mahir ve kendi alanında otorite olmasının (alan bilgisi) yanı sıra diğer ilim dallarından da haberdar olmalı (genel kültür) ve kendisini sürekli geliştirmelidir. Öğretmen sahip olduğu ilmi daha ileri bir seviyeye çıkarma gayreti içinde olmalı ve işini severek yapmalıdır. İslam tarihinde bazı âlimler, en zor durumlarda bile ders vermeyi ihmal etmemişler ve bunun bir şifa kaynağı olduğuna inanmışlardır. Ancak bu şartlar altında bir öğretmenin öğrencilerine faydalı olabileceği, böylece onların saygısını-sevgisini kazanabileceği ve bu mesleği sevdirebileceği kabul edilmiştir. ${ }^{5}$ Osmanlı Devleti döneminde de din ve ahlak eğitiminin ağırlıklı olduğu mekteplerde görev yapan öğretmenlerin seçiminde ilk dönemlerde, ilim sahibi, ahlaklı, yumuşak huylu, dindar olmak gibi bazı şartları taşıyanlara berat verilerek görevlendirme yapılmışır. ${ }^{6}$

Günümüzde, öğretmenlik mesleğini başarılı bir şekilde yerine getirebilmek, tüm öğretmenler için geçerli olan genel yeterliklerin yanı sıra her branş öğretmeni için ayrı tanımlanmış olan özel alan yeterliklerine de sa-

\footnotetext{
3 Uygulama Öğrencilerinin Millî Eğitim Bakanlığına Bağlı Eğitim Öğretim Kurumlarında Yapacakları Ögrretmenlik Uygulamasına İlişkin Yönerge (UÖMEBBEÖKYÖYİY), Öğretmen Yetiştirme ve Geliştirme Genel Müdürlüğü (2018), md. 6/10.

4 Ahmed Çelebi, İslâmda Eğitim Öğretim Târihi, çev. Ali Yardım (İstanbul: Damla Yayınevi, 1983), 208, 209.

5 M. Faruk Bayraktar, İslâm Eğitiminde Öğretmen-Öğrenci Münâsebetleri (İstanbul: M. Ü. İlahiyat Fakültesi Vakfı Yayınları, 2015), 159-165.

6 Mustafa Öcal, Osmanlı'dan Günümüze Türkiye'de Din Eğitimi (İstanbul: Dergah Yayınları, 2017), 35-38.
} 
hip olmayı gerektirmektedir. Genel yeterlikler içinde, mesleki bilgi, mesleki beceri, tutum ve değerlerden oluşan üç farklı yeterlik alanı bulunmaktadır. Mesleki bilgi yeterliği, alan bilgisine, alan eğitimi bilgisine ve mevzuat bilgisine sahip olmayı; mesleki beceri yeterliği, eğitim öğretimi planlama bilgisine sahip olmayı, öğrenme ortamları oluşturmayı, öğretme-öğrenme sürecini yönetmeyi, ölçme ve değerlendirmeyi; tutum ve değerler yeterliğ $i$ ise milli, manevi ve evrensel değerleri gözetmeyi, öğrenciye yaklaşımı, iletişim ve işbirliğini, kişisel ve mesleki gelişimi kapsamaktadır. ${ }^{7}$ Bu genel çerçevenin yanı sıra, Din Kültürü ve Ahlak Bilgisi dersi öğretmenlerinin, dersin içeriğine uygun yöntem, teknik ve teknolojik imkanları kullanabilmesi, öğrencinin din olgusunu tanımasına rehberlik etmesi, inancın hayata kattığı değerleri fark ettirmesi, inanç-ibadet-davranış ilişkisini kavratabilmesi, Hz. Peygamberin örnek ahlakını ve nasıl modellenebileceğini göstermesi gibi özel alan yeterliklerine de sahip olması gerekmektedir. ${ }^{8}$ Bunların gerektiği şekilde yerine getirilmesi, hem din derslerinin verimli bir şekilde işlenmesini hem de aday öğretmenlere başarılı bir şekilde rehberlik edilebilmesini sağlayacaktır.

Din dersi öğretmenlerinin, yukarıda ifade edilen yeterlikleri taşıması gerekli olmakla birlikte yüksek din öğretiminin programı bunun için tam anlamıyla elverişli değildir. Günümüzde uygulamada olan İlahiyat Lisans Programında bölümleşmenin olmaması, öğretmen yetiştirme sürecine etki eden sorunlarından biridir. Her ne kadar pedagojik formasyon dersleri 2017-2018 eğitim-öğretim yılından itibaren programda yer alsa da farklı amaçlar için özelleştirilmiş bir program çerçevesinde derslerin verilmemesi sorun yaratmaktadır. ${ }^{9}$ Bu durum, öğrencinin mezun olmadan önce hedefini belirlemesi ve öğretmen olacaksa, o alanda kendisini yetiştirmesi adına ciddi bir eksikliktir. Buna bir de duyuşsal ve psikomotor davranış kazandırmadaki yetersizliği, yüz yüze eğitim imkanından mahrum olması ve örgün eğitim mezunlarıyla aynı diplomayı kazandırması bakımından çokça eleştirilen ${ }^{10}$ İLITAM gibi uzaktan eğitim uygulamalarını eklediğinizde, sorunun boyutu daha da büyümektedir.

7 Öğretmen Yetiştirme ve Geliştirme Genel Müdürlüğü (ÖYGM), “Öğretmenlik Mesleği Genel Yeterlikleri" (Erişim 27 Kasım 2019).

8 Öğretmen Yetiştirme ve Geliştirme Genel Müdürlüğü (ÖYGM), “Din Kültürü ve Ahlak Bilgisi Öğretmeni Özel Alan Yeterlikleri” (Erişim 24 Ocak 2020).

9 Bayramali Nazıroğlu, "İlahiyat Fakültelerinde Din Eğitimi ve Sorunları", Türkiye'de Din Ĕ̆itimi ve Sorunları, ed. Mustafa Köylü (İstanbul: Dem Yayınları, 2018); İbrahim Turan, "Türkiye'de İlahiyat Eğitimi: İstihdam Alanı-Program İlişkisi Üzerine BirDeğerlendirme", İstanbul Üniversitesillahiyat Fakültesi Dergisi 37 (Aralık 2017),69-74.

${ }^{10}$ Nazıroğlu, "Yüksek Din Öğretimi”, 156. 
Gerek tarihsel süreçte yaşanan iniş çıkışlar gerekse din dersi öğretmeni yetiştiren yüksek din öğretimi kurumlarının kendi içinde yaşadığ 1 problemler, bu okullardan mezun olan öğrencilerin mesleki verimliliği üzerinde etkili olabilecek türdendir. Son yıllarda İlahiyat Fakültelerinin ve bu fakültelere alınan öğrencilerin sayısı çokça artmış olmasına rağmen, bu niceliksel artışın kaliteden tavizi de beraberinde getirip getirmediği sorgulanmaktadır. ${ }^{11} \mathrm{Bu}$ nedenle, din dersi öğretmenlerinin değerlendirildiği çalışmalar literatürde belirli aralıklarla karşımıza çıkmaktadır. ${ }^{12}$

\section{ARAŞTIRMANIN AMACI VE ÖNEMI}

Bu çalışma, İHL meslek dersleri öğretmenliği ya da DKAB öğretmenliği alanında öğretmenlik uygulaması yapan öğretmen adaylarının uygulama öğretmenlerini, öğretmenlik uygulaması sürecinde edindiği görüş ve izlenimleri doğrultusunda değerlendirmeleri amacıyla hazırlanmıştır. Lisans eğitiminin ya da lisans sürecinin ardından pedagojik formasyon eğitiminin son döneminde bu uygulamayı yapan ve 14 haftalık staj uygulaması süresince haftada altı saat uygulama öğretmenini gözlemleme imkanına sahip olan öğretmen adaylarının, öğretmenlik mesleğini yapabilecek teorik bilgiye sahip olması, uygulama öğretmenleri hakkında yaptığı değerlendirmeyi anlamlı kılmakta ve diğer çalışmalardan farklılaştırmaktadır. Ayrıca, din dersi öğretmenlerinin değerlendirilmesi yoluyla elde edilecek bilgiler, eğitim kurumlarını ilgilendiren konularda yeniden düzenlemelere gidilmesine de katkı sağlayacaktır.

Araştırmanın amacına yönelik olarak şu sorular hazırlanmıştır:

${ }^{11}$ Bk. Mustafa Köylü, “Türkiye'de Yüksek Din Öğretimi: Nicelik miNitelik mi?”, Ondokuz Mayls Üniversitesi İlahiyat Fakültesi Dergisi 35 (2013), 21-44; Hacı Mustafa Kiriş, "Diyanet İşleri Başkanlığı Personel Yeterlikleri Bağlamında İlahiyat Fakültesi Lisans Programlarının İşlevselliği", Cumhuriyet Üniversitesi Edebiyat Fakültesi Sosyal Bilimler Dergisi 42/2 (2018), 47-76.

${ }^{12}$ Bk. Hüseyin Algur, İlköğretim İkinci Kademe Din Kültürü ve Ahlak Bilgisi Derslerinde Öğretmen-Ö̆grenci İletişimi (Bayrampaşa Örneği) (İstanbul: Marmara Üniversitesi, Sosyal Bilimler Enstitüsü, Yüksek Lisans Tezi, 2009); Ahmet Koç, “Din Kültürü ve Ahlâk Bilgisi Öğretmenlerinin Yeterlikleri", Değerler Eğitimi Dergisi 8/19 (Haziran 2010), 107-149; Süleyman Akyürek, "İmam-Hatip Lisesi Meslek Dersi ile Din Kültürü ve Ahlak Bilgisi Dersi Öğretmenlerinin Eğitim-Öğretim Yeterliklerine İlişkin Algıları", Değerler Eğitimi Dergisi 10/23 (Haziran 2012), 7-47; Hatice Fakioğlu Bağc1, Illköğretim Din Kültürü ve Ahlak Bilgisi Öğretmenlerinin Sını Yönetimi Yeterlikleri (Beykoz Örneği) (İstanbul: Marmara Üniversitesi, Sosyal Bilimler Enstitüsü, Yüksek Lisans Tezi, 2012); Mahmut Zengin, “Din Kültürü ve Ahlak Bilgisi Öğretmenlerinin Eğitim Öğretim Yeterlik Algıları", Sakarya Üniversitesi İlahiyat Fakültesi Dergisi 15/27 (2013), 1-28; İbrahim Aşlamacı, Paydaşlarına Göre İmam-Hatip Ortaokullarında Din Eğitimi (İstanbul: Dem Yayınları, 2017); Muhammet Mesut Yıldız, Din Kültürü ve Ahlak Bilgisi Öğretmenlerinin Kendi Algılarına Göre Sinıf Yönetimi Becerileri (Erzurum: Atatürk Üniversitesi, Eğitim Bilimleri Enstitüsü, Yüksek Lisans Tezi, 2019). 
İlahiyat alanında pedagojik formasyon eğitimi alan öğretmen adayları, öğretmenlik uygulamasında kendilerine rehberlik eden uygulama öğretmenlerini alan bilgisi bakımından nasıl değerlendirmektedir?

İlahiyat alanında pedagojik formasyon eğitimi alan öğretmen adaylarl, öğretmenlik uygulamasında kendilerine rehberlik eden uygulama öğretmenlerini öğrencilerle iletişimi bakımından nasıl değerlendirmektedir?

İlahiyat alanında pedagojik formasyon eğitimi alan öğretmen adaylarl, öğretmenlik uygulamasında kendilerine rehberlik eden uygulama öğretmenlerini sınıf yönetimi bakımından nasıl değerlendirmektedir?

İlahiyat alanında pedagojik formasyon eğitimi alan öğretmen adaylarl, öğretmenlik uygulamasında kendilerine rehberlik eden uygulama öğretmenlerini derse hazırlık yapma bakımından nasıl değerlendirmektedir?

İlahiyat alanında pedagojik formasyon eğitimi alan öğretmen adayları, öğretmenlik uygulamasında kendilerine rehberlik eden uygulama öğretmenlerini mesleğe yönelik tutumu bakımından nasıl değerlendirmektedir?

Din dersi öğretmenleri, derslerde genellikle hangi öğretim yöntem ve tekniklerini kullanmaktadır?

İlahiyat alanında pedagojik formasyon eğitimi alan öğretmen adaylarına göre din dersi öğretmeninde olması gereken en önemli özellik nedir?

İlahiyat alanında pedagojik formasyon eğitimi alan öğretmen adayları, uygulama öğretmenleri rehberliğinde yaptıkları öğretmenlik uygulamasını nasıl değerlendirmektedir?

\section{ARAŞTIRMANIN YÖNTEMI}

İlahiyat alanında pedagojik formasyon eğitimi alan öğretmen adaylarının uygulama öğretmenlerini değerlendirdiği bu çalışmada, betimsel araştırma modellerinden olan tarama yöntemi kullanılmıştır. Verilerin toplanmasında hem nitel hem de nicel veriler elde etmek amacıyla araştırmacı tarafından bir kısmı açık bir kısmı da kapalı uçlu olmak üzere toplam 19 sorudan oluşan bir anket formu hazırlanmış ve uzman görüşlerine başvurularak ankete son şekli verilmiştir.

Araştırmada katılımcların belirlenmesinde, seçkisiz olmayan örnekleme yöntemlerinden uygun örnekleme yöntemi kullanılmıştır. Araştırmanın evrenini, 2016-2017 ve 2017-2018 eğitim-öğretim yılında, Amasya Üniversitesi Eğitim Fakültesi tarafından yürütülen pedagojik formasyon programına ilahiyat alanında devam eden öğretmen adayları oluşturmaktadır. 2016-2017 eğitim-öğretim yılında yapılan ilk uygulamada yeterli sa- 
yıda anket dönüşü olmadığı için bir sonraki yıl öğrenim gören pedagojik formasyon öğrencilerine de anket uygulanmıştır. Öğrencilerin bir kısmı bu dersten muaf ${ }^{13}$ olduğu gerekçesiyle anketleri yanitlamamış, bir kısmı anketleri doldurmayı kabul etmemiş, bir kısmının ise anketleri geçersiz kabul edilmiş ve neticede dağıtılan 395 anketten 332'si değerlendirmeye alınabilmiştir. Bu anketler SPSS veri analiz programına yüklenerek frekans tabloları elde edilmiştir. Ankette yer alan açık uçlu sorulara verilen cevaplar ise müstakil ve karşılaştırmalı olarak yorumlanmıştır.

\section{BULGULAR VE YORUM}

Araştırmaya katılan 332 kişinin 98'i (\%29,5) erkek, 234'ü (\%70,5) kadındır. Katılımcıların 260'1 (\%78,3) İHL'den, 72'si (\%21,7) diğer liselerden mezun olmuştur. $4^{\prime}$ ü $(\% 1,2)$ ilahiyat fakültesi (örgün eğitim) mezunu, 305'i $(\% 91,9)$ ilahiyat fakültesi son sınıf öğrencisi, $11^{\prime}$ i $(\% 3,3)$ İLİTAM mezunu, 11'i $(\% 3,3)$ İLİTAM son sınıf öğrencisidir. Bir öğrenci ise diğer seçeneğini işaretleyerek İşletme lisans mezunu olduğunu belirtmiştir. Araştırmaya katılanların 21'i (\%6,3) Diyanet İşleri Başkanlığında görevli, 7'si (\%2,1) DİB dışındaki bir devlet kurumunda ya da özel sektörde görevlidir. Katılımcıların 304'ü (\%91,6) ise herhangi bir işte çalışmadığını belirtmiştir.

Yukarıda kişisel bilgileri verilen katılımcıların anket sorularına verdiği yanıtlarla ilgili tablolar ve yorumları aşağıda verilmiştir. ${ }^{14}$

Tablo 1: Öğretmen Adaylarının Uygulama Öğretmenlerinin Alan Bilgisine Dair Görüşlerine Göre Dağılımı

\begin{tabular}{lcc}
\hline Uygulama Öğretmeninin Alan Bilgisi & $\mathbf{N}$ & $\mathbf{\%}$ \\
\hline Çok iyi & 115 & 34,7 \\
Iyi & 165 & 49,8 \\
Orta & 46 & 13,9 \\
Yetersiz & 5 & 1,5 \\
Toplam & 331 & 100,0 \\
\hline
\end{tabular}

\footnotetext{
${ }^{13}$ Pedagojik formasyon eğitimi alan öğretmen adaylarının bir kısmı, özel öğretim kurumlarında veya MEB'e bağlı okullarda öğretmenlik yaptığı ya da yapmakta olduğu için öğretmenlik uygulaması dersinden muaf tutulabilmektedir. Bk. Pedagojik Formasyon Eğitimi Sertifika Programına İlişkin Çerçeve Usul ve Esaslar (PFESPIÇ̧UE), Yükseköğretim Kurulu (2015), md. 4.

${ }^{14}$ Anket kapsamında sorulan soruların bir kısmına araştırmanın kapsamını aşacağından bir kısmına da anlamlı farklılık yaratacak bir sonuç sağlamadığından, bulgular kısmında yer verilmemiştir.
} 
Araştırmaya katılan öğretmen adaylarından, uygulama öğretmenlerini alan bilgisi bakımından değerlendirmeleri istenmiş, soruyu cevaplayan katılımcıların \%34,7'si uygulama öğretmenlerinin alan bilgisinin "çok iyi", \%49,8'i “iyi", \%13,9'u "orta" ve \%1,5'i "yetersiz" olduğunu belirtmiştir.

Din dersi öğretmenlerinin kendilerini değerlendirdiği çalışmalara bakıldığında, benzer şekilde bir dağılımın olduğu görülmektedir. Yorulmaz tarafından yapılan araştırmada, Temel Dini Bilgiler dersini vermek için alan bilgisini, öğretmenlerin \%37,8'i "her zaman", \%52,5'i “çoğunlukla”, \%8,9'u "bazen" yeterli bulduğunu, \%0,7'si ise “hiçbir zaman” yeterli bulmadığını, ${ }^{15} \mathrm{~Hz}$. Muhammed'in hayatını bilme konusunda \%25,4'ü kendisini "çok iyi”, \%57,6'sı "iyi”, \%16,1'i “orta" ve \%0,9'u "yetersiz" bulduğunu, ${ }^{16}$ Kur'an-1 Kerim öğretim yöntemleri konusunda ise \%14,6's1 kendisini "Çok iyi", \% 51,9'u “İyi", \%27,9'u "Orta", \%5,6's1 "Yetersiz" bulduğunu belirtmiştir. ${ }^{17}$ Çelik tarafından yapılan araştırmada, DKAB öğretmeniyle ilgili olarak "Akademik olarak dersine ve konusuna hâkimdir" ifadesine öğrencilerin; \%5,4’ü "Kesinlikle Katılmıyorum”, \%2,7'si “Katılmiyorum", \%10,8'i “Kararsızım", \%32,8'i “Katılıyorum" ve \%48,4'ü ise "Tamamen Katılıyorum" cevabını vermiştir. ${ }^{18}$

Öğretmenlik uygulamasındaki uygulama öğretmenlerinin değerlendirildiği benzer bir çalışma Eğitim Fakültesi son sınıf öğrencileriyle yapılmış, öğrencilerin \%39,8'i, staj uygulamasındaki öğretmenlerini, öğretmenlik becerisi bakımından "kısmen yeterli" bulurken \%30,5'i "yeterli", \%18,6's1 "oldukça yeterli", \%11'i "yetersiz" bulduğunu belirtmiştir. ${ }^{19} \mathrm{Bu}$ çalışmayla kıyaslandığında, yukarıdaki tablodaki sonuçların, daha olumlu değerlendirmeler içerdiği görülmektedir. İlahiyat alanında öğretmenlik uygulaması yapan adaylar, alan bilgisi konusunda uygulama öğretmenlerini önemli oranda yeterli bulmuştur.

${ }^{15}$ Bilal Yorulmaz, "Din Kültürü ve Ahlak Bilgisi Öğretmenlerinin Seçmeli Kur'an-1 Kerim, Hz. Muhammed'in Hayatı ve Temel Dini Bilgiler Derslerine İlişkin Öz Algıları", Marmara Üniversitesi Öneri Dergisi 11/41 (2014), 319.

${ }^{16}$ Yorulmaz, "Din Kültürü ve Ahlak Bilgisi Öğretmenlerinin Seçmeli Kur'an-1 Kerim, Hz. Muhammed'in Hayatı ve Temel Dini Bilgiler Derslerine İlişkin Öz Algıları", 315.

17 Yorulmaz, "Din Kültürü ve Ahlak Bilgisi Öğretmenlerinin Seçmeli Kur'an-1 Kerim, Hz. Muhammed'in Hayatı ve Temel Dini Bilgiler Derslerine İlişkin Öz Algıları", 307.

${ }^{18}$ Zeynep Çelik, Din Kültürü ve Ahlak Bilgisi Öğretiminde Öğretmen Davranışları (Çınarcık Örneği) (Sakarya: Sakarya Üniversitesi, Sosyal Bilimler Enstitüsü, Yüksek Lisans Tezi, 2010), 41.

${ }^{19}$ Nida Bayındır vd., "Öğretmen Adaylarının İdeal Öğretimsel Becerilere İlişkin Beklentileri”, Uşak Üniversitesi Sosyal Bilimler Dergisi 9/1 (2016), 85. 
Tablo 2: Öğretmen Adaylarının Uygulama Öğretmenlerinin Öğrencilerle İletişimine Dair Görüşlerine Göre Dağılımı

\begin{tabular}{lll}
\hline $\begin{array}{l}\text { Uygulama Öğretmeninin } \\
\text { Ögrencilerle İletişimi }\end{array}$ & $\mathbf{N}$ & $\mathbf{\%}$ \\
\hline Çok iyi & 113 & 34,1 \\
İyi & 152 & 45,9 \\
Orta & 46 & 13,9 \\
Yetersiz & 20 & 6,0 \\
Toplam & 331 & 100,0 \\
\hline
\end{tabular}

Soruyu cevaplayan katılımcllardan, uygulama öğretmenlerinin öğrencileriyle iletişimini "çok iyi" şeklinde tanımlayanların oranı \%34,1, "iyi" şeklinde tanımlayanların oranı \%45,9, "orta" şeklinde tanımlayanların oranı \%13,9 ve "yetersiz" bulanların oranı \%6'dır. Buna göre, öğrencilerle iletişim konusunda din dersi öğretmenlerinin çoğunluğunun başarılı bulunduğu söylenebilir.

Koç tarafından, İHL meslek dersleri öğretmenlerinin yeterlikleri üzerine yapılan bir araştırmada öğretmenler, öğrenciyi tanıma ve öğrenciyle ilişkiler boyutundaki yeterliklerden 4'üne "tam", 9'una da "oldukça" düzeyinde sahip oldukların belirtmişlerdir. ${ }^{20}$ Illköğretim DKAB öğretmenleri üzerine yapılan bir araştırmada da etkili iletişim bilgi ve tekniklerini kullanma boyutunda belirtilen yeterliklerin 15'ine "tam", 13'üne de "oldukça" düzeyinde sahip oldukları tespit edilmiştir. ${ }^{21}$ Zengin tarafından yapılan çalışmada, DKAB öğretmenlerinin "Sınıf içinde sevgi ve saygıya dayalı etkili iletişimi sağlayabilme", "Olumlu davranışları övme ve içsel pekiştireçleri kullanabilme" gibi iletişime dair nitelikler açısından kendilerini "oldukça yeterli" gördükleri tespit edilmiştir. ${ }^{22}$ Akyürek tarafından

\footnotetext{
${ }^{20}$ Ahmet Koç, “İmam Hatip Lisesi Meslek Dersleri Öğretmenlerinin Yeterlikleri Üzerine Bir Araştırma", C.Ü. İlahiyat Fakültesi Dergisi 13/2 (2009), 150.

${ }^{21}$ Iş1 Yazıc1, İlköğretim Din Kültürü ve Ahlak Bilgisi Öğretmenleri Yeterlikleri (İstanbul İli Örneği Üzerinde Bir Alan Araştırması) (Ankara: Ankara Üniversitesi, Sosyal Bilimler Enstitüsü, Yüksek Lisans Tezi, 2004), 132.

${ }^{22}$ Zengin, "Din Kültürü ve Ahlak Bilgisi Öğretmenlerinin Eğitim Öğretim Yeterlik Algıları”, 14.
} 
yapılan araştırmada da din eğitimi öğretmenlerinin iletişim becerileri konusunda kendilerini oldukça yeterli buldukları görülmüştür. ${ }^{23}$ Çelik'in çalışmasında ise DKAB öğretmenleriyle ilgili olarak "Öğrencileri etkin bir biçimde dinler" ifadesine öğrencilerin $\% 47,9^{\prime}$ u; "Öğrenci ile etkileşimde empati geliştirir/yapar." ifadesine öğrencilerin \%20,5'i; "Sevgi, saygı, duygu, düşünce ve becerisini paylaşır." ifadesine \%33,3'üu, "Her Zaman" yanıtını vermiştir. ${ }^{24}$ Buna göre öğrencilerin algılarıyla öğretmenlerin özalgıları arasında kısmen farklılık bulunmaktadır.

Gordon, etkili bir öğretmen olabilmek için en temel unsurun öğretmen-öğrenci ilişkisi olduğunu belirtmiştir. Herhangi bir konunun ya da bir inancın öğrenci için anlamll, heyecan verici veya ilginç kılınması, öğretmenin öğrencisiyle iyi bir iletişim kurabilmesine bağlıdır. Bu ilişkide her iki taraf da birbirlerinin gereksinimlerine saygı göstermek zorundadir. ${ }^{25} \mathrm{Bu}$ nedenle, din eğitimcilerinin iletişim konusunda kendilerini daima geliştirme çabası içinde olmaları ve özeleştiri yapmalarının yanı sıra, dışarıdan gelen eleştirilere de açık olmaları oldukça önemlidir.

Tablo 3: Öğretmen Adaylarının Uygulama Öğretmenlerinin Sınıf Yönetimine Dair Görüşlerine Göre Dağılımı

\begin{tabular}{lll}
\hline $\begin{array}{l}\text { Uygulama } \\
\text { Ögretmeninin Sınıf } \\
\text { Yönetimi Becerisi }\end{array}$ & $\mathbf{N}$ & $\mathbf{\%}$ \\
\hline Çok iyi & 111 & 33,5 \\
İyi & 139 & 42,0 \\
Orta & 67 & 20,2 \\
Yetersiz & 14 & 4,2 \\
Toplam & 331 & 100,0 \\
\hline
\end{tabular}

Araştırmaya katılan öğretmen adaylarından, uygulama öğretmenlerinin sinıf yönetimi becerilerini değerlendirmeleri istenmiş, soruyu cevaplayan katılımclların \%33,5'i "çok iyi", \%42'si "iyi", \%20,2'si "orta", \%4,2'si de "yetersiz" bulduğunu belirtmiştir.

Kars tarafından yapılan araştırmada, DKAB öğretmenlerinin sınıf yö-

${ }^{23}$ Akyürek, "İmam-Hatip Lisesi Meslek Dersi ile Din Kültürü ve Ahlak Bilgisi Dersi Öğretmenlerinin Eğitim-Öğretim Yeterliklerine İlişkin Algıları", 24.

${ }^{24}$ Çelik, Din Kültürü ve Ahlak Bilgisi Öğretiminde Öğretmen Davranışları, 46- 48.

25 Thomas Gordon, E. Ö. E. Etkili Öğretmenlik Ĕ̆itimi, çev. Emel Aksay (İstanbul: Sistem Yayıncilik, 2000), 4. 
netimi etkinliklerine önem verdiği, bunları "çoğu zaman" sergilediği ve sınıf yönetimi bakımından da kendilerini "yüksek düzeyde yeterli" algıladığ tespit edilmiştir. ${ }^{26}$ Akyürek tarafından yapılan ve hem İHL meslek dersi öğretmenlerinin hem de DKAB öğretmenlerinin katıldığı bir araştırmada, öğretmenlerin sinıf yönetimi konusunda kendilerini yeterli buldukları tespit edilmiştir. Öğretmenler, "Öğrencilere sınıfta kendilerini özgürce ifade edebilecekleri öğrenme ortamı sağlama”, “Öğrencilere gerekli yerlerde ipucu verme" ve "Olumlu davranışları övme ve içsel pekiştireçleri kullanma" alt başlıklarında ise kendilerini "oldukça yeterli" şeklinde tanımlamışlardır. ${ }^{27}$ Bağ $\mathrm{C}$ tarafından yapılan araştırmada ise DKAB öğretmenleri genel olarak sinıfa hâkimiyetlerini "normal", "iyi", "olumlu", "ortalama", "yeterli" şeklinde tanımlamışlar; öğretmenlerin sadece \%10'u sınıfa hakimiyetlerinin oldukça iyi olduğunu belirtmiştir. ${ }^{28}$

Sınıfın fiziksel özelliklerini düzenlemekten sınıf içi etkileşime, sınıf kurallarını belirlemekten zaman yönetimine kadar pek çok boyutu olan sinıf yönetiminde en önemli öğe öğretmendir ve verdiği doğru kararlarla süreci başarıyla yönetebilmesi gerekir. Bir öğretmenin sınıf yönetimi anlayışında, aldığı eğitimin niteliği, görev süresi, mesai arkadaşlarıyla iletişimi ve beklentileri gibi birçok faktör etkili olmaktadır. ${ }^{29}$

Günümüzde yaşanan toplumsal değişmeyle birlikte, öğrencilerin tutum ve bilgi seviyeleri yanında eğitim sistemi de farklılaşmıştır. Öğrencilerin bilişim teknolojileri aracılığıyla daha fazla bilgiye erişme imkanını elde etmesi, otoriteye saygının yok olması; buna rağmen öğretmen yetiştirme sürecinin sınıf yönetimi konusunda verdiği bilginin sınırlı olması, öğretmenlerin bilgi ve yeterliklerini sürekli geliştirme çabası içinde olmalarını gerektirmektedir. ${ }^{30}$ Din dersi öğretmenlerinin sorumluluğu ise bu durumda biraz daha fazladır. Çünkü bir yandan belirli kurallar dahilinde dersi yöneterek bilgi aktarımını sağlaması diğer yandan da duygu boyutu ağırlıklı olan bu eğitim sürecinde kontrolü kaybetmeden gereken etkiyi bırakabilmesi lazımdır.

\footnotetext{
${ }^{26}$ Yunus Emre Kars, Din Kültürü ve Ahlak Bilgisi Öğretmenlerinin Kendi Algılarına Dayalı Sınıf Yönetimi Yeterlikleri (Konak İlçesi Örneği) (İzmir: Dokuz Eylül Üniversitesi, Sosyal Bilimler Enstitüsü, Yüksek Lisans Tezi, 2007), 60-61.

${ }^{27}$ Akyürek, "İmam-Hatip Lisesi Meslek Dersi ile Din Kültürü ve Ahlak Bilgisi Dersi Öğretmenlerinin Eğitim-Öğretim Yeterliklerine İlişkin Algıları", 23.

${ }^{28}$ Fakioğlu Bağcl, İlköğretim Din Kültürü ve Ahlak Bilgisi Öğretmenlerinin Sinıf Yönetimi Yeterlikleri, 173-174.

${ }^{29}$ Zülfü Demirtaş, Sınıf Yönetimi (İstanbul: AZ Kitap, 2019), 20.

${ }^{30}$ Mehmet Okutan, "Disiplin Problemlerinin Sürekliliği", Sinıf Yönetimi, ed. Emin Karip (Ankara: Pegem Akademi, 2017), 5-9.
} 
Tablo 4: Öğretmen Adaylarının Uygulama Öğretmenlerinin Derse Hazırlıklı Gelmesine Dair Görüşlerine Göre Dağılımı

\begin{tabular}{lll}
\hline $\begin{array}{l}\text { Uygulama Öğretmeninin Derse } \\
\text { Hazırlıklı Gelme Durumu }\end{array}$ & $\mathbf{N}$ & \% \\
\hline Her zaman ön hazırlık yapar & 170 & 51,7 \\
Zaman zaman ön hazırlık yapar & 124 & 37,7 \\
Ön hazırlık yapmadan derse girer & 35 & 10,6 \\
Toplam & 329 & 100,0 \\
\hline
\end{tabular}

Araştırmaya katılan öğretmen adaylarına, öğretmenlik uygulaması için girdikleri derslerde dersin öğretmenini derse hazırlık yapma bakımından nasıl değerlendirdikleri sorulmuş, uygulama öğretmeninin her ders için ön hazırlık yaptığını belirtenlerin oranı $\% 51,7$, zaman zaman ön hazırlık yaptığını belirtenlerin oranı $\% 37,7$ ve ön hazırlık yapmadan derse girdiğini belirtenlerin oranı \%10,6 çıkmıştır.

Çelik tarafından yapılan çalışmada, ölçekte yer alan "Her derse hazırlıklı girer" ifadesine öğrencilerin \%4,9'u "Kesinlikle Katılmıyorum", \%3,2'si "Katılmıyorum", \%14,1'i "Kararsızım" cevabını verirken \%31,9'u "Katılıyorum" ve \%45,9'u ise "Tamamen Katılıyorum" yanıtını vermiştir. ${ }^{31}$ Bağcının yaptığ 1 çalışmada ise DKAB öğretmenlerinin \%55'i zaman zaman, \%20'si haftalık ve \%15'i her zaman hazırlık yaptığını belirtirken, $\% 10^{\prime}$ u hazırlık yapmadığını ifade etmiştir. ${ }^{32}$

Derse hazırlıklı gelme konusundaki hassasiyetin bir benzeri olarak, Aşlamacı'nın yaptığı araştırmada elde ettiği sonuçlar oldukça anlamlıdır. Araştırmada, İHO öğretmenlerine din eğitimine ilişkin derslerin öğretim programlarını inceleme durumları sorulmuş, hepsini kapsamlı inceleyenlerin oranı $\% 23$, ana hatlarıyla göz atanların oranı $\% 35,2$, yalnızca girdiği dersleri inceleyenlerin oranı $\% 37,8$, hiç incelemeyenlerin oranı $\% 4,1$ çıkmıştır. ${ }^{33}$

Öğretmenlerin eğitim-öğretim dönemi başında ders programlarını inceleyerek başlaması gereken hazırlık süreci, haftalık program için de düzenli olarak devam etmelidir. Derse hazırlık yapmak, tecrübe sahibi olanlar için olduğu kadar göreve yeni başlayanlar için de gereklidir. Bilginin sürekli güncellenmesi ve yaşamın içinden örneklerle desteklenmesi, dersin farklı öğretim yöntem ve teknikleriyle zenginleştirilebilmesi için bu

${ }^{31}$ Çelik, Din Kültürü ve Ahlak Bilgisi Öğretiminde Öğretmen Davranışları, 41.

${ }^{32}$ Fakioğlu Bağcl, İlköğretim Din Kültürü ve Ahlak Bilgisi Öğretmenlerinin Sinıf Yönetimi Yeterlikleri, 89.

${ }^{33}$ Aşlamac1, Paydaşlarına Göre İmam-Hatip Ortaokullarında Din Eğitimi, 183. 
hazırlık kaçınılmazdır. Bu hem öğretmenin ve öğrencinin motivasyonuna hem de derslerin daha verimli bir şekilde işlenmesine katkı sağlar. Yukarıdaki tabloya göre, araştırma kapsamındaki din dersi öğretmenlerinin yaklaşık yarısının, düzenli bir hazırlık yapmadan derse girmesi ise bu anlamda dersin veriminin düşmesine neden olabilecek bir etkendir.

Tablo 5: Öğretmen Adaylarının Uygulama Öğretmenlerinin Mesleğe Yönelik Tutumlarına Dair Görüşlerine Göre Dağılımı

\begin{tabular}{lll}
\hline $\begin{array}{l}\text { Uygulama Öğretmeninin Mesleğe } \\
\text { Yönelik Tutumu }\end{array}$ & N & \% \\
\hline Mesleğini severek yapar & 275 & 83,1 \\
Mesleğini kısmen sever & 52 & 15,7 \\
Mesleğinden hoşlanmaz & 4 & 1,2 \\
Toplam & 331 & 100,0 \\
\hline
\end{tabular}

Öğretmen adaylarına, uygulama öğretmenlerinin mesleğe yönelik tutumuyla ilgili değerlendirmeleri sorulmuş, \%83,1'i uygulama öğretmeninin mesleğini severek yaptığını, \%15,7'si mesleğini kısmen sevdiğini, $\% 1,2$ 'si mesleğinden hoşlanmadığını belirtmiştir.

Koç tarafından yapılan araştırmada, DKAB öğretmenlerinin "tam" düzeyinde sahip olduklarını düşündükleri yeterliklerden biri "mesleğini severek, benimseyerek yapma" olmuştur. Bu soruya ankete katılan öğretmenlerin \%58' $\mathrm{i}$ "her zaman" ve \%35'i de "çoğunlukla" cevabını vermiştir. ${ }^{34}$ Algur tarafından yapılan çalışmada, öğrencilerin \%73,1'i DKAB öğretmeninin mesleğini severek yaptığına dair cümleyi "kesinlikle katılıyorum" seçeneğini işaretleyerek onaylamıştır..$^{35}$ Aşlamacı tarafından yapılan çalışmada da İHO okulu öğrencilerinin öğretmenlere ilişkin algılarının oldukça olumlu olduğu ve "Okulumuzdaki öğretmenler işlerini özveriyle ve severek yapar" ifadesinin de benzer şekilde algılandığ $(X=3,86)$ tespit edilmiştir. ${ }^{36}$

Yeğin tarafından yapılan araştırmada, DKAB öğretmenlerinin duygusal boyutta tükenmişliklerinin orta, duyarsızlaşma ve kişisel başarı boyutlarındaysa düşük düzeyde olduğu tespit edilmiştir. ${ }^{37}$ Bunda, cinsiyetin,

\footnotetext{
${ }^{34}$ Koç, "Din Kültürü ve Ahlâk Bilgisi Öğretmenlerinin Yeterlikleri", 118, 120.

${ }_{35}$ Algur, İlköğretim İkinci Kademe Din Kültürü ve Ahlak Bilgisi Derslerinde Öğretmen-Öğrenci İletişimi, 82.

36 Aşlamac1, Paydaşlarına Göre İmam-Hatip Ortaokullarında Din Ĕ̆itimi, 204-205.

${ }^{37}$ Hüseyin İbrahim Yeğin, "Din Kültürü ve Ahlâk Bilgisi Öğretmenlerinin Tükenmişlik Düzeyleri", Ekev Akademi Dergisi 58 (Kış 2014), 322.
} 
yaşın, medeni durumun, mesleki kıdemin, görev yapılan okul türünün ve mesleği tercih nedeninin anlamlı bir farklılık yarattığı görülmüştür.

Kişinin hayatının önemli bir parçası olan mesleğini sevmesi hem yaşam enerjisini arttıracak hem de görevin gerektirdiklerini daha başarılı bir şekilde yerine getirmesine katkıda bulunacak bir özelliktir. Bu olumlu gelişmeler elbette, öğrenciyle, okul idarecileriyle, diğer öğretmen ve velilerle kurulan iletişime de olumlu yansıyacaktır. Yukarıdaki tabloya göre din dersi öğretmenlerinin çoğunun meslek sevgisinin üst düzeyde çıması sevindirici olmakla birlikte yaklaşık beş öğretmenden birinin bu konuda öretmen adaylarına olumlu mesajlar vermediğini de hesaba katmak gerekir. Bu, Yeğin'in araştırmasında ortaya koyduğu orta düzey bir tükenmişliği akla getirdiği gibi henüz tespit edilmemiş farklı türden nedenleri de incelemeyi gerektirmektedir.

Tablo 6: Öğretmen Adaylarının Uygulama Öğretmenlerinin Kulland1ğ Öğretim Yöntem ve Tekniklerine Dair Görüşlerine Göre Dağılımı

\begin{tabular}{|c|c|c|c|c|c|c|c|c|c|}
\hline $\begin{array}{l}\text { Öğretim } \\
\text { Yöntem ve } \\
\text { Teknikleri }\end{array}$ & 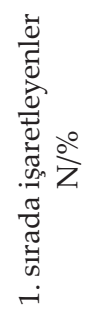 & 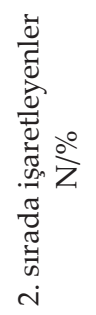 & 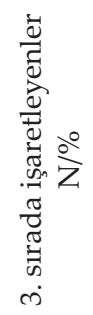 & 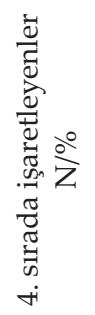 & 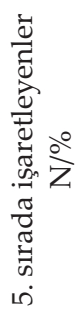 & 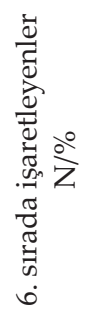 & 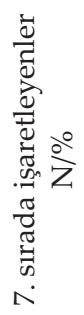 & $\begin{array}{l}\frac{N}{\omega} \\
\frac{2}{2} \\
\text { Uं }\end{array}$ & 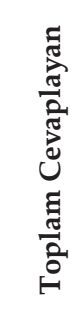 \\
\hline Anlatim & $\begin{array}{c}269 \\
\% 81,0\end{array}$ & $\begin{array}{c}27 \\
\% 8,1\end{array}$ & $\begin{array}{c}17 \\
\% 5,1\end{array}$ & $\begin{array}{c}2 \\
\% 0,6\end{array}$ & $\begin{array}{c}1 \\
\% 0,3\end{array}$ & $\begin{array}{c}2 \\
\% 0,6\end{array}$ & - & $\begin{array}{c}14 \\
\% 4,2\end{array}$ & $\begin{array}{c}318 \\
\% 95,8\end{array}$ \\
\hline Tartışma & $\begin{array}{c}6 \\
\% 1,8\end{array}$ & $\begin{array}{c}50 \\
\% 15,1\end{array}$ & $\begin{array}{c}177 \\
\% 53,3\end{array}$ & $\begin{array}{c}11 \\
\% 3,3\end{array}$ & $\begin{array}{c}1 \\
\% 0,3\end{array}$ & $\begin{array}{c}1 \\
\% 0,3\end{array}$ & $\begin{array}{c}1 \\
\% 0,3\end{array}$ & $\begin{array}{c}85 \\
\% 25,6\end{array}$ & $\begin{array}{c}247 \\
\% 74,4\end{array}$ \\
\hline Soru-cevap & $\begin{array}{c}41 \\
\% 12,3\end{array}$ & $\begin{array}{c}210 \\
\% 63,3\end{array}$ & $\begin{array}{c}43 \\
\% 13,0\end{array}$ & $\begin{array}{c}2 \\
\% 0,6\end{array}$ & $\begin{array}{c}1 \\
\% 0,3\end{array}$ & - & - & $\begin{array}{c}35 \\
\% 10,5\end{array}$ & $\begin{array}{c}297 \\
\% 89,5\end{array}$ \\
\hline $\begin{array}{c}\text { Küme } \\
\text { çalışması }\end{array}$ & $\begin{array}{c}1 \\
\% 0,3\end{array}$ & $\begin{array}{c}5 \\
\% 1,5\end{array}$ & $\begin{array}{c}14 \\
\% 4,2\end{array}$ & $\begin{array}{c}75 \\
\% 22,6\end{array}$ & $\begin{array}{c}22 \\
\% 6,6\end{array}$ & $\begin{array}{c}4 \\
\% 1,2\end{array}$ & - & $\begin{array}{c}211 \\
\% 63,6\end{array}$ & $\begin{array}{c}121 \\
\% 36,4\end{array}$ \\
\hline Dramatizasyon & - & $\begin{array}{c}3 \\
\% 0,9\end{array}$ & $\begin{array}{c}6 \\
\% 1,8\end{array}$ & $\begin{array}{c}16 \\
\% 4,8\end{array}$ & $\begin{array}{c}73 \\
\% 22\end{array}$ & $\begin{array}{c}12 \\
\% 3,6\end{array}$ & - & $\begin{array}{c}222 \\
\% 66,9\end{array}$ & $\begin{array}{c}110 \\
\% 33,1\end{array}$ \\
\hline Gezi-gözlem & $\begin{array}{c}4 \\
\% 1,2\end{array}$ & $\begin{array}{c}3 \\
\% 0,9\end{array}$ & $\begin{array}{c}5 \\
\% 1,5\end{array}$ & $\begin{array}{c}8 \\
\% 2,4\end{array}$ & $\begin{array}{c}7 \\
\% 2,1\end{array}$ & $\begin{array}{c}83 \\
\% 25,0\end{array}$ & $\begin{array}{c}2 \\
\% 0,6\end{array}$ & $\begin{array}{c}220 \\
\% 66,3\end{array}$ & $\begin{array}{c}112 \\
\% 33,7\end{array}$ \\
\hline Diğer & $\begin{array}{c}2 \\
\% 0,6\end{array}$ & $\begin{array}{c}2 \\
\% 0,6\end{array}$ & $\begin{array}{c}12 \\
\% 3,6\end{array}$ & $\begin{array}{c}2 \\
\% 0,6\end{array}$ & $\begin{array}{c}1 \\
\% 0,3\end{array}$ & - & $\begin{array}{c}2 \\
\% 0,6\end{array}$ & $\begin{array}{c}311 \\
\% 93,7\end{array}$ & $\begin{array}{c}21 \\
\% 6,3\end{array}$ \\
\hline
\end{tabular}


Ankete katılan öğretmen adaylarından, uygulama öğretmenlerinin derste kullandığı yöntem ve teknikleri sıklık durumuna göre sıralamaları istenmiştir. Öğrencilerin bir kısmı, yalnızca bir ya da birkaç seçeneği işaretleyerek cevap verirken, bazıları da tüm seçenekleri sıralamaya dahil etmiştir. Buna göre 1. sırada en çok ifade edilen ve en çok öğrenci tarafından işaretlenen yöntem "Anlatım" olmuştur. 2. sırada en çok seçilen yöntem "Soru-cevap", 3. sırada en çok tercih edilen yöntem ise "Tartışma"dır. Diğer seçeneğini işaretleyenlerin verdiği cevaplar arasında ise "Beyin fırtınası", “Oyun", "Akıllı tahta", “Videolar, sunumlar", "Karşılıklı diyalog", "Hayat için nasihatler", "Küçük grup tartışması" yer almaktadır. Bu tabloya göre denilebilir ki, din dersi öğretmenleri genellikle geleneksel yöntemlerle dersi işlemeye devam etmektedir. Her ne kadar din derslerinin içeriği anlatım yöntemini gerekli kılsa da bu, dersin farklı yöntem ve tekniklerle zenginleştirilemeyeceği anlamına gelmemektedir. Oysa yukarıdaki tabloya göre, dersi farklı yöntemlerle zenginleştiren öğretmen sayısı çok da fazla değildir.

Günümüz eğitim sistemi içinde bilişim teknolojilerinin birçok alanda sağladığı önemli katkılar vardır. Bu teknolojinin kullanımının, eğitimde planlama, yönetim, değerlendirme, iletişim ve mesleki gelişim alanına yaptığı katkıların yanı sıra, sağladığı çeşitlilik ile farklı öğrenme türündeki öğrencilere hitap edebilmeye, öğrencilerin derse aktif katılımına, anlatılan konunun kalıcılığına da katkısı vardır ve öğrencinin derse karşı motivasyonunu arttırmaktadır..$^{38}$ IDKAB dersine giren sinıf ve branş öğretmenleri üzerine yapılan bir araştırmaya göre, öğretim teknolojileri alanındaki yeterlikler içinde öğretmenlerin en az düzeyde sahip olduğu üç yeterlikten biri "Eğitimde bilgisayarlardan etkin bir şekilde yararlanma"dır. ${ }^{39}$ Akyürek tarafından yapılan araştırmada öğretmenler, öğretimi planlama konusunda kendilerini yeterli görmekle birlikte birtakım eksiklikleri bulunduğunu, en çok da materyal belirleme konusunda eksiklikleri olduğunu belirtmişlerdir. ${ }^{40}$ Güneş tarafından yapılan araştırmada, büyük çoğunluğu $(\% 92,68) 40$ yaşın altında olan DKAB öğretmenlerinin teknolojik materyal kullanımına ihtiyaç duydukları ancak gerek okullardaki donanımın ye-

${ }_{38}$ İbrahim Turan, "Öğretmen Eğitimi ve Bilişim Teknolojileri”, Aday Öğretmenler İçin Okul Deneyimi ve Öğretmenlik Uygulaması, ed. İsmail Hakkı Demircioğlu (Ankara: Anı Yayıncılık, 2015), 198-199.

${ }^{39}$ Eyüp Şimşek, “Din Kültürü ve Ahlak Bilgisi Dersi Öğretmenlerinin Öğretim Teknolojileri Alanındaki Yeterlikleri", Atatürk Üniversitesi Sosyal Bilimler Enstitüsü Dergisi 22/3 (Eylül 2018), 1639.

${ }^{40}$ Akyürek," İmam-Hatip Lisesi Meslek Dersi ile Din Kültürü ve Ahlak Bilgisi Dersi Öğretmenlerinin Eğitim-Öğretim Yeterliklerine İlişkin Algıları", 19. 
tersiz olmasından gerekse kendilerinden kaynaklanan nedenlerden ötürü teknolojik materyal kullanımının istenilen düzeye erişemediği tespit edilmiştir. ${ }^{41}$ Aşlamacı'nın yaptığı araştırmada da İHO DKAB öğretmenlerinin öğretim sürecindeki yeterliklerine ilişkin algılarında en düşük ortalamaya sahip oldukları yeterlikler arasında özgün öğretim materyali hazırlama ve derste etkileşimli tahtayı etkin şekilde kullanma yer almıştır. Bu konuda öğrenciler de öğretmenlerle hemfikirdir ve DKAB öğretmenlerinin derslerde teknolojik imkanları etkili bir şekilde kullanmasına ilişkin madde hem öğrenciler hem de öğretmenler tarafından yapılan değerlendirmede en düşük ortalamaya sahiptir. ${ }^{42}$

Tablo 5'e göre, öğretmenlerin yaklaşık yarısının, dersler için düzenli hazırlık yapmadığı tespit edilmiştir. Bunun sebeplerinden biri de farklı yöntem ve teknikler kullanmamaları olabilir. Şöyle ki, anlatım, soru-cevap ve tartışma yöntemi, başarılı bir şekilde kullanıldığı durumlar hariç, diğer yöntem ve teknikler kadar hazırlık gerektirmemektedir. Bu da doğru kullanılmayan anlatım ve soru-cevap yönteminin yaygınlaşmasına, dersin tekdüzeleşmesine ve sonuçta öğrencinin ilgisinin dağılmasına neden olabilmektedir.

Son dönemlerde okulların önemli bir kısmına kurulmuş olan etkileşimli tahtalar aracılığıyla ders anlatımı yaygınlaşmaktadır. Her ne kadar yaptığımız çalışmada akıllı tahta kullanımına dair kesin bir veri elde edilemese de din dersi öğretmenleri tarafından akıllı tahtanın kullanıldığı “ $\mathrm{Di}$ ğer" seçeneğine yapılan açıklamalarda belirtilmiştir. Konuyla ilgili yapılan bir araştırmada, öğrenciler derslerde akıllı tahta kullanımından memnun olduklarını, akıllı tahta üzerinden işlenen derslerden daha çok keyif aldıklarını, akıllı tahta kullanıldığında derse daha iyi odaklandıklarını ve birçok şeyi öğrenebildiklerini ifade etmişlerdir. ${ }^{43}$ Buna göre, anlatım yöntemini tercih eden din dersi öğretmenlerinin en azından etkileşimli tahtada var olan görsellerden yararlanarak da olsa bilişim teknolojilerinin sağlayacağ 1 katkıdan istifade etmeleri önemlidir.

${ }^{41}$ Adem Güneș, “DKAB Dersinde Teknolojik Materyal Kullanımı ve DKAB Öğretmenlerinin Teknolojik Materyal Kullanma Eğilimleri (Gaziantep İli Örneği)", Cumhuriyet Üniversitesi İlahiyat Fakültesi Dergisi 16/1 (2012), 479.

${ }^{42}$ Aşlamacı, Paydaşlarına Göre İmam-Hatip Ortaokullarında Din Ĕ̆itimi, 193.

${ }^{43}$ Meltem Sünkür vd., "Akıllı Tahta Uygulamaları Konusunda İlköğretim II. Kademe Öğrencilerinin Görüşleri (Malatya İli Örneği)", e-Journal Of New World Sciences Academy 7/1 (2012), 317. 
Tablo 7: Öğretmen Adaylarının Öğretmenlik Uygulamasını Faydalı Bulma Durumuna Göre Dağılımı

\begin{tabular}{lll}
\hline $\begin{array}{l}\text { Öğretmenlik Uygulamasını Faydalı } \\
\text { Bulma Durumu }\end{array}$ & $\mathbf{N}$ & $\mathbf{\%}$ \\
\hline Evet, oldukça faydalıydı & 249 & 75,7 \\
Kısmen faydalıydı & 74 & 22,5 \\
Hayır, faydalı değildi & 6 & 1,8 \\
Toplam & 329 & 100,0 \\
\hline
\end{tabular}

Öğretmen adaylarına, uygulama öğretmenlerinin rehberliğinde yaptıkları öğretmenlik uygulamasını faydalı bulup bulmadıkları sorulmuş, soruyu cevaplayanların \%75,7'si faydalı bulduğunu, \%22,5'i kısmen faydalı bulduğunu, \%1,8'i ise faydalı bulmadığını belirtmiştir.

“Bu dönem, okullarda yaptığınız öğretmenlik uygulamasının faydalı olduğunu düşünüyor musunuz?" sorusuna verilen cevaplar doğrultusunda, faydalı olduğunu düşünenlere, uygulamanin ne tür bir katkısı olduğu sorulmuştur. Katılımcıların tamamına yakını bunun iyi bir tecrübe olduğunu ve bu sayede eksikliklerini görebildiklerini ve heyecanlarını kısmen yendiklerini belirtmişlerdir. Bu olumlu düşüncelerin oluşmasında, uygulama öğretmenlerinin etkinliği de cevaplarda görülmektedir. Konuyla ilgili verilen cevaplardan bazıları şöyledir:

"Yapılan ders anlatımında yanınızda bilen birisi bulunuyor ve münasip bir dille sizi uyarıyor. Eğer direkt derse girildiği düşünülürse yapılacak hatalar büyük sorunlara ulaştırabilir."

"Bu uygulama bence çok yararlı. Biraz yorucu olsa da öğretmenliğe ilk adımda güzel bir şey. Ön hazırlık gibi. İnsana tecrübe kazandırıyor. Çocuklarla nasıl iletişime geçeceğimizi, ders işleniş şekillerini öğreniyoruz."

Öğretmenlik uygulamasının faydalı olduğunu düşünenlerin yanı sıra, kısmen faydalı olduğunu ya da faydalı olmadığını düşünen katılımcılar da vardır. Uygulama hakkında olumsuz düşünceye sahip olan öğretmen adayları bunu, daha ziyade uygulama öğretmeninin ilgisizliğine veya yetersizliğine, uygulama okulundaki idareci ve öğretmenlerin tutumlarına, uygulamanın süresine ve zamanlamasına bağlamışlardır. Bu soruya verilen cevaplardan bazıları şöyledir:

“Öğretmen sınıfı tamamen bıraktı. Yol, yöntem fazla göstermedi. Sadece stajın ilk günü derse katılıp dinledim daha sonra bu yolla devam etmemizi istedi." 
"Biz öğretmenlik uygulamasında ders anlatmadık. Uygulama öğretmenimiz bize karşı çok soğuk davrandı. Biz okula gittiğimizde bize selam bile vermedi. Bunun için ben öğretmenlik uygulamasının bana herhangi bir katkı sağladığını kesinlikle düşünmüyorum."

"Notlar nasıl girilir, plan nasıl hazırlanır, ders defterleri nasıl doldurulur, bunlar anlatılmiyor."

"Olumsuz yönü: Son sınıfa sıkıştırılması ve çok titiz davranılmaması."

Yukarıda verilen cevaplardan hareketle, öğretmen adaylarının uygulamada karşılaştıkları en önemli sorunlardan biri, uygulama öğretmenlerinin ilgisizliği veya uygulama hakkındaki yönergeye uymamalarıdır. Oysa Öğretmenlik Uygulama Yönergesi'ne göre uygulama öğretmeni öğrencisine rehberlik etmekle, onun etkinliklerini izleyip değerlendirmekle sorumludur. $\mathrm{Bu}$ değerlendirme de en az dört kez yapılmalıdır. Okul içerisindeki eğitim öğretim faaliyetleri kadar aday öğretmenlere yapılacak bu rehberlik çalışmaları da önemli bir görev alanıdır. Uygulama eğitim kurumu müdürü ise gerekli görevlendirmeleri yaptıktan sonra uygulama çalışmalarının verimli bir şekilde gerçekleştirilmesi için gerekli önlemleri almalı ve uygulama öğretmenlerinin çalışmalarını denetlemelidir. ${ }^{44}$ Teoride böyle olması gerekirken, pratikte uygulamanın farklı şekilde gerçekleştiğini ifade eden öğretmen adayları, bu nedenle sürecin kendileri adına verimli geçmediğini düşünmektedir. Okullardaki bazı öğretmenler, aday öğretmenlerine tamamıla sorumluluklarını devretmiş, bazıları ise aday öğretmene yönergede belirtilen süreden (Uygulama öğrencisi fiilen 14 saatten az ders anlatmamalıdır) daha az ders anlatma fırsatı vermiştir. Her iki durumda da öğrencinin uygulamadan gereken verimi elde etmesine engel olunmuştur. Bunda ise hem uygulama öğretmeninin hem uygulama eğitim kurumu müdürünün hem de uygulama öğretim elemanının ihmali bulunmaktadır. Benzer bir sonuç Ören ve arkadaşları tarafından yapılan araştırmada ${ }^{45}$ da ortaya çıkmıştır. Bu çalışmada öğretmen adaylarının uygulama okulunda karşılaştıkları problemlerin öncelikle okul idaresinden $(\% 33,9)$, ikinci sırada ise uygulama öğretmenlerinden kaynaklandiğ $(\% 26,8)$ tespit edilmiş̧ir.

Anket kapsamında sorulan bir diğer açık uçlu soru, uygulama sürecindeki gözlemlerin ve eğitim kurumlarında aldıkları teorik bilgilerin 1şığında, bir DKAB ya da meslek dersi öğretmeninde bulunması gereken en

${ }^{44}$ UÖMEBBEÖKYÖYIY, md. 6/8, 6/10.

${ }^{45}$ Fatma Şaşmaz Ören vd., "Öğretmen Adaylarının Okul Deneyimi Derslerine Yönelik Tutumlarının ve Görüşlerinin Değerlendirilmesi", Kuram ve Uygulamada Eğitim Yönetimi 15/58 (2009), 234. 
önemli özelliğin ne olduğudur. Bu soruya katılımcıların verdiği cevaplar arasında, "alan bilgisine hakimiyet, öğrencilerle sağlıklı bir iletişim kurmak, rol model olmak, mesleğini ve öğrencilerini sevmek, sınıf hakimiyetini sağlayabilmek, öğrencinin seviyesine göre dersi anlatabilmek, teknolojiyi kullanmak, derse hazırlıklı gelmek, sabırlı ve güler yüzlü olmak, hitabeti iyi olmak, özgüven sahibi olmak, bakımlı olmak" yer almaktadır. Bu cevaplardan bazıları şöyledir:

"Birincisi öğretmen sahasında çok yetkin olmall, ikincisi işine kendini adamalı, üçüncüsü samimi ve içten olmalı, toplumla hemhal olmalı."

"İşini severek yapması en önemli özellik bence. Sevgisiz yapılan bir iş ne öğretmene ne de öğrenciye faydalı olmaz. Aynı zamanda sabır da önemli bir etmen. Özellikle ortaokullarda yapılan görevler gerçekten sabır istiyor. Dersine gereken önemi vermesi ve derse her daim hazır gelmesi de yine önemli bir etmen."

“Teknolojiye ve güncel olaylara hâkim, işlediği konuyu güncel ve yaşanmış olaylarla anlatabilen, öğretici ve eğitici materyaller kullanarak oyun ve eğlence şeklinde ders işleyen, empati kurabilen ve eşit davranan."

“Bence en önemli özellik, öğrencinin ilgi ve hazırbulunuşluk düzeyini bilip buna göre eğitimini şekillendirmesidir. Yani bilgiden çok, bilgisini istenilen ölçüde sunmaktır önemli olan."

“ilk dikkat etmesi gereken konunun kılık kıyafeti olduğunu düşünüyorum. İlk algı çok önemli, DKAB öğretmenine uygun olmalı. Sonra da önemli olan içindeki meslek sevgisi... Diğer bir konu da çocuk sevgisi."

“Objektif olarak öğrenciye yaklaşmalı! Çünkü her inanıştan öğrenci olabiliyor. Bunları dinden soğutmayacak bir karakterde ve davranışta olmalı. Öğrencilere dini sevdirmeyi başarabilmeli. Onların kâbusu olmamalı!!!"

Pedagojik formasyon eğitimi alan öğretmen adaylarının, uygulama okulundaki gözlemleri sonucunda "İyi bir öğretmen nasıl olmalıdır?" sorusuna verdiği cevap şekillenmektedir. Bunlar arasında iyi örnekler olduğu gibi, zaman zaman da istenmeyen durumlarla karşılaşılabilmektedir. İyi örnekler ilham verici olurken, olumsuzluklar eleştiriye neden olmaktadır. Yukarıdaki ifadelerden hareketle, öğrencilerin farklı başarı düzeyindeki öğretmenlerin rehberliğinde uygulamalarını yaptıkları ve bunlardan kendilerine birtakım dersler çıkardıkları görülmektedir. Bununla ilgili olarak bir katılımcının şu cevabı oldukça düşündürücüdür: "Hocaların sınıfa hakimiyetini görmüş oldum. Bilgi seviyelerini görmüş oldum. Ben öğretmen olduğumda daha farklı olmayı düşünüyorum." 
Gökçe ve Demirhan tarafından yapılan araştırmada, ${ }^{46}$ uygulama öğretmenlerinin kişilik özellikleri, tutum ve davranışları ile kendileri için nitelikli bir model olması ile ilgili soruya öğretmen adaylarından "Hiçbir zaman" cevabını verenlerin oranı \%11,2, "Nadiren" cevabını verenlerin oranı \%12,4, "Bazen" cevabını verenlerin oranı ise \%23,9 çıkmıştır. İlginç olan ise uygulama öğretmenlerinin bu konuda daha olumlu etki bıraktıklarına inanmalarıdır. Öğretmenlerin \%68, 4 'ü "her zaman" nitelikli bir öğretmen olmaya çalıştığını ifade ederken, aday öğretmenlerin yalnızca \%28'i uygulama öğretmenlerinin "Her zaman" kendileri için nitelikli bir model olduğunu belirtmiştir. Araştırma sonucunda da öğretmen adayı ve uygulama öğretmeni arasındaki iş birliğinin yeterli düzeyde olmadığı ve konuyla ilgili olarak uygulama öğretmenleri ile aday öğretmenlerin görüşleri arasında anlamlı bir farklılık olduğu ortaya çıkmıştır.

Çelik tarafından yapılan araştırmada öğretmen adaylarına, nitelikli bir öğretmende bulunması gereken kişisel değerler sorulmuştur. Öğrencilerin verdiği cevaplar çokluk derecesine göre, ahlaklı olmak, milli ve manevi değerlere saygılı olmak, kendini yenileyip geliştirebilmek, özgüvenli olmak, idealist olmak, dürüstlük, adil olmak, çalışkanlık, davranışlarını kontrol etmek, samimi olmak, tahammüllü olmak, güler yüzlü olmak, demokrat olmak şeklinde sıralanmıştır. ${ }^{47}$ Süral ve Sarıtaş tarafından yapılan araştırmada, pedagojik formasyon eğitimi alan öğrenciler, bir öğretmende bulunması gereken en önemli yeterliklerin $(\% 42,7)$ "bireysel farklılıkları dikkate alma", "dersi planlama" (\%23) ve "öğrenme ortamlarını düzenleme" (\%14,7) olduğunu belirtmişlerdir. ${ }^{48}$ Bir diğer araştırmada ise öğretmen adaylarının çağdaş bir öğretmenin sahip olması gereken nitelikler arasında en yüksek önem atfettiklerinin "sorumluluk duygusuna sahip olmak" ve "değişime açık olmak" olduğu tespit edilmiştir. ${ }^{49}$

Acuner ve Erbaş tarafindan yapılan araştırmada ise olayı farklı bir bakış açısıyla ele alarak din dersi öğretmeni için en önemli yeterliklerin neler oldu-

${ }^{46}$ Erten Gökçe - Canay Demirhan, "Öğretmen Adaylarının ve İlköğretim Okullarında Görev Yapan Uygulama Öğretmenlerinin Öğretmenlik Uygulaması Etkinliklerine İlişkin Görüşleri", Ankara Üniversitesi Eğitim Bilimleri Fakültesi Dergisi 38/1 (2005).

${ }^{47}$ Firat Çelik, Öğretmen Adaylarının Öğretmenlik Mesleği Genel Yeterlik Algılarının Değerlendirilmesi (Diyarbakır: Dicle Üniversitesi, Eğitim Bilimleri Enstitüsü, Yüksek Lisans Tezi, 2013), 57.

${ }^{48}$ Serhat Süral - Emel Sarıtaş, "Pedagojik Formasyon Programına Katılan Öğrencilerin Öğretmenlik Mesleğine Yönelik Yeterliklerinin İncelenmesi", Mersin Üniversitesi Eğitim Fakültesi Dergisi 11/1 (Nisan 2015), 66.

${ }^{49}$ Abdurrahman İlğan vd., "Pedagojik Formasyon Programı Öğretmen Adaylarının Mesleki Tutum ve Çağdaş Öğretmen Algıları", Ondokuz Mayıs Üniversitesi Eğitim Fakültesi Dergisi 32/2 (2013), 187. 
ğu hem DKAB öğretmenlerine hem de kurumdaki diğer branş öğretmenlerine sorulmuştur. Sonuçta, DKAB öğretmenlerinin kendilerinde 1. derecede görmek istedikleri yeterlik alanı "Alan Bilgisi" $(\% 62,3)$ olurken, diğer branş öğretmenlerinin DKAB öğretmenlerinde 1. derecede görmek istedikleri yeterlik alanının "Kişisel ve Mesleki Özellikler" (\%42,3) olduğu tespit edilmiştir. ${ }^{50}$ Buna göre, din dersi öğretmenleri her ne kadar kendilerini bilgi bakımından donatmayı önceleseler de çevrelerindeki insanların onlardan beklentisi, daha iyi birer rol model olmalarıdır. Bir diğer araştırmada da öğrencilerin önemli bir kısmının (\%40), DKAB öğretmenlerinden beklentilerinin diğer branş öğretmenlerinden beklentilerinden daha fazla olduğu ortaya çımıştır. ${ }^{51}$

Anketin son sorusunda, aday öğretmenlerin uygulama süreciyle ilgili belirtmek istedikleri diğer hususları yazmaları istenmiştir. Buna cevap veren katılımcıların bir kısmı gözlemledikleri öğretmen ve öğrenci davranışlarını eleştirmiş ve uygulamada karşılaştıkları sorunlara çözüm önerileri geliştirmişlerdir. Bu soruya konumuzla ilgili verilen cevaplardan bir kısmı şöyledir:

“Öğretmenler bir süre sonra mesleğin önemini unutup para kazanma derdine düşüyor. Üzücü bir durum. 'Anlatır çıkarım' mantı̆̆ı oldukça fazla. Yillar sonra böyle bir öğretmen olmak istemiyorum."

“Öğretmenlik yaptı̆̆ım yerde hocalar genelde yaşlı oluyorlar. Ders yöntem ve tekniklerini pek kullanamıorlar."

"Kendi staj danışman hocam çok yeterli ama çeşitli arkadaşların hocası öğrencileri aşağılıyor, dışlıyor, ağlatıyor ve daha kötüsü."

"Danışman hocalarımızın, staj, sunu vs gibi konularda, bilgilendirme hususunda daha ayrıntılı bilgi vermeleri bizim açımızdan iyi olur."

“Uygulama için gittiğimiz okullarda bulunan öğretmenler acemiliğimizi kullanarak bizim sorumluluğumuzda olmayan şeyleri bize yüklüyorlar. Bu konuda bir çözüm bulunmalı."

\section{SONUÇ}

Din dersi öğretmeni gerek mesleki bilgi ve becerisi gerek sahip olduğu tutum ve değerleri gerekse de öğrencileriyle ve eğitimin diğer paydaşlarıyla arasında kurduğu iletişim bakımından en iyiye erişme gayreti içinde

\footnotetext{
${ }^{50}$ Hacı Yusuf Acuner - Ahmet Akif Erbaş, "Din Kültürü ve Ahlak Bilgisi ve Diğer Branş Öğretmenlerine Göre Din Kültürü ve Ahlak Bilgisi Öğretmenlerinin Yeterlikleri", Dinbilimleri Akademik Araştırma Dergisi 16/1 (2016), 159.

${ }^{51}$ Mukadder Bulut, İlköğretim Öğrencileri ve Velilerinin Bakış Açısıyla İdeal Din Kültürü ve Ahlak Bilgisi Öğretmeni Profili (İstanbul: Marmara Üniversitesi, Sosyal Bilimler Enstitüsü, Yüksek Lisans Tezi, 2009), 69.
} 
olmalıdır. Bunun başarılmasında öğretmen yetiştiren kurumların olduğu kadar öğretmenin kendisini geliştirmek ve daha kaliteli bir eğitim verebilmek için gösterdiği çabanın da katkısı bulunmaktadır.

Çalışma kapsamında görüşleri alınan öğretmen adayları uygulama öğretmenlerini alan bilgisi ve iletişim konusunda büyük oranda "iyi" veya "çok iyi" şeklinde tanımlamış, sınıf yönetiminde ise bu oran çok az da olsa düşüş göstermiştir. Aday öğretmenlerin çoğunluğu, uygulama öğretmenlerinin öğretmenlik mesleğini sevdiğini ancak derse hazırlıklı gelmek konusunda yaklaşık yarısının düzenli bir alışkanlığı olmadığını belirtmiştir. Bu durum, derste kullanılan yöntem ve tekniklere de yansıyarak genel itibariyle klasik yöntemlerin kullanılmasını berberinde getirmiştir. Araştırma kapsamında elde edilen bu sonuçların büyük oranda, literatürdeki benzer diğer çalışma sonuçlarıyla paralel olduğu da tespit edilmiştir.

Öğretmen adaylarının öğretmenlik uygulaması süresince, olumlu ya da olumsuz düşüncelere sebep olan gözlemleri, neticede öğretmenlik mesleğine dair bakış açılarını ve ideal din eğitimcisinin nasıl olması gerektiği düşüncesini şekillendirmiştir. Öğretmen adayları, uygulama öğretmeninde ya da genel olarak okul ortamında gördükleri olumsuzluklardan dersler çıkarmışlar, olumlu olarak değerlendirdikleri yönleri ise kendilerine örnek alacaklarını ifade etmişlerdir.

Son dönemde, öğretmen adaylarına daha verimli bir biçimde rehberlik edebilmesi için öğretmenlerin, MEB tarafından verilen Öğretmenlik Uygulaması Eğitimi Sertifikası'na sahip olması şartı getirilmiştir ${ }^{52}$ Konuyla ilgili olarak da Milli Eğitim Bakanlığı, İl Milli Eğitim Müdürlüklerine gönderdiği yazıda, Öğretmenlik Uygulaması Danışmanlığı Eğitimi Kursu düzenlenmesini, ${ }^{53}$ Il Uygulama Koordinatörlerinin, Fakülte-Okul İş Birliği Protokolü çerçevesinde üniversitelerle işbirliği yaparak gerçekleştireceği bu seminerlere katılmayan öğretmenlere uygulamada görev verilmemesini istemiştir..$^{54} \mathrm{Bu}$ doğrultuda İl ve İlçe Milli Eğitim Müdürlükleri, eğitim seminerlerini gerçekleştirmiştir (ÖYGM, 28 Kasım 2019). Ancak uygulama, bu araştırma yapıldıktan sonra gerçekleştirilmiştir. Teorik olarak faydalı olacağı düşünülen bu uygulamanın pratikte ne kadar yarar sağlayacağı ayrıca araştırılmaya değerdir. Bu uygulama, aday öğretmenleri yetiştirecek olanları ilgilendirirken, uygulama öğret-

${ }^{52}$ UÖMEBBEÖKYÖYIY, md. 4/g, 4/1.

${ }^{53}$ MEB Öğretmen Yetiştirme ve Geliştirme Genel Müdürlüğünün 43501582-774.01.01E.5586019 Sayı ve 16.03.2018 Tarihli Yaz1s1.

${ }^{54}$ MEB Öğretmen Yetiştirme ve Geliştirme Genel Müdürlüğünün 31666252-399-E.13465016 Sayı ve 11.09.2017 Tarihli Yazısı. 
meni olmayan din dersi öğretmenlerinin eksikliklerinin giderilmesi için de ayrı çalışmalar planlanması gerekmektedir.

Din dersi öğretmenlerinin, dersi daha etkili hale getirmek için farklı öğretim yöntem ve teknikleri konusunda kendilerini geliştirmeleri en az, alan bilgisine hakimiyet kadar önemli bir konudur. Teknoloji çağında yetişen çocukların uzun süreli anlatımları etkileyici bulmaması ve odaklanma sorunları yaşaması muhtemeldir. Bu nedenle din eğitimcileri öğrenciyi aktif kılacak yöntem ve teknikleri tanıma gayreti içinde olmalı ve bunlar için zaman ayırmalıdır. Kendilerini yetersiz hissettikleri konular hakkında hizmet içi eğitim faaliyetleri düzenlenmesini talep edebilecekleri gibi konuyla ilgili basılı materyalleri ya da internet ortamında paylaşılan eğitimsel ürünleri de düzenli olarak takip etmelidirler.

Din dersi öğretmenleri hakkında yapılan bazı olumsuz değerlendirmeler, alana yönelik herhangi bir sınav yapılmaksızın merkezi bir sınavla ilahiyat fakültelerine yapılan yerleştirmenin ne kadar geçerli olduğunu sorgulamaya bizi götürmektedir. Konuyla ilgili olarak, liselerde mesleki rehberlik çalışmalarına ağırlık verilmesi, bilinçsizce yapılan tercihlerin önüne geçebilecektir. Bunun yanı sıra ilahiyat fakültelerinde okuyan öğrencilerin, bu yoğun eğitim programına sorunsuz bir şekilde uyum sağlayabilmesi ve aidiyet duygusu yaşayabilmesi için öğrencilerle iletişimin devamlı olması; bölümleşmenin olmadığı bu fakülte içerisinde hangi görev alanının kendilerine daha uygun olacağı konusunda mesleki rehberliğin yapılması da faydalı olacaktır. 


\section{KAYNAKÇA}

Acuner, Hacı Yusuf - Erbaş, Ahmet Akif. “Din Kültürü ve Ahlak Bilgisi ve Diğer Branş Öğretmenlerine Göre Din Kültürü ve Ahlak Bilgisi Öğretmenlerinin Yeterlikleri". Dinbilimleri Akademik Araştırma Dergisi 16/1 (2016), 147-170.

Akyürek, Süleyman. “İmam-Hatip Lisesi Meslek Dersi ile Din Kültürü ve Ahlak Bilgisi Dersi Öğretmenlerinin Eğitim-Öğretim Yeterliklerine İlişkin Algılar1". De ğerler Ĕ̆itimi Dergisi 10/23 (Haziran 2012), 7-47.

Algur, Hüseyin. İlköğretim İkinci Kademe Din Kültürü ve Ahlak Bilgisi Derslerinde Ö $\breve{g}$ retmen-Öğrenci İletişimi (Bayrampaşa Örneği). İstanbul: Marmara Üniversitesi, Sosyal Bilimler Enstitüsü, Yüksek Lisans Tezi, 2009.

Aşlamacı, İbrahim. Paydaşlarına Göre İmam-Hatip Ortaokullarında Din Ĕ̆itimi. İstanbul: Dem Yayınları, 2017.

Bayındır, Nida vd. “Öğretmen Adaylarının İdeal Öğretimsel Becerilere İlişkin Beklentileri”. Uşak Üniversitesi Sosyal Bilimler Dergisi 9/1 (2016), 79-88.

Bayraktar, M. Faruk. İslâm Ĕ̆itiminde Öğretmen-Öğrenci Münâsebetleri. İstanbul: M. Ü.İlahiyat Fakültesi Vakfı Yayınları, 10. Basım, 2015.

Bulut, Mukadder. İlköğretim Öğrencileri ve Velilerinin Bakış Açısıyla İdeal Din Kültürü ve Ahlak Bilgisi Öğretmeni Profili: İstanbul Örneği. İstanbul: Marmara Üniversitesi, Sosyal Bilimler Enstitüsü, Yüksek Lisans Tezi, 2009.

Çelebi, Ahmet. İslâmda Ĕğitim Öğretim Târihi. çev. Ali Yardım. İstanbul: Damla Yayınevi, 1983.

Çelik, Fırat Öğretmen Adaylarının Öğretmenlik Mesleğgi Genel Yeterlik Algılarının Değerlendirilmesi. Diyarbakır: Dicle Üniversitesi, Eğitim Bilimleri Enstitüsü, Yüksek Lisans Tezi, 2013.

Çelik, Zeynep. Din Kültürü ve Ahlak Bilgisi Öğretiminde Öğretmen Davranışları (Çınarcık Örneği). Sakarya: Sakarya Üniversitesi, Sosyal Bilimler Enstitüsü, Yüksek Lisans Tezi, 2010.

Demirtaş, Zülfü. Sınıf Yönetimi. İstanbul: AZ Kitap, 3. Basım, 2019.

Fakioğlu Bağc1, Hatice. İlköğretim Din Kültürü ve Ahlak Bilgisi Öğretmenlerinin Sınf Yönetimi Yeterlikleri (Beykoz Örneği). İstanbul: Marmara Üniversitesi, Sosyal Bilimler Enstitüsü, Yüksek Lisans Tezi, 2012.

Gordon, Thomas. E. Ö. E. Etkili Öğretmenlik Ĕ̆itimi. çev. Emel Aksay. İstanbul: Sistem Yayıncilık, 2000.

Gökçe, Erten - Demirhan, Canay. “Öğretmen Adaylarının ve İlköğretim Okullarında Görev Yapan Uygulama Öğretmenlerinin Öğretmenlik Uygulaması Etkinliklerine İlişkin Görüşleri”. Ankara Üniversitesi Ĕ̆itim Bilimleri Fakültesi Dergisi 38/1 (2005), 43-7. 
Güneş, Adem. “DKAB Dersinde Teknolojik Materyal Kullanımı ve DKAB Öğretmenlerinin Teknolojik Materyal Kullanma Eğilimleri (Gaziantep İli Örneği)", Cumhuriyet Üniversitesi İlahiyat Fakültesi Dergisi 16/1 (2012), 479-506.

İlğan, Abdurrahman vd. “Pedagojik Formasyon Programı Öğretmen Adaylarının Mesleki Tutum ve Çağdaş Öğretmen Algıları". Ondokuz Mayıs Üniversitesi Ĕ̆itim Fakültesi Dergisi 32/2 (2013), 175-195.

Kars, Yunus Emre. Din Kültürü ve Ahlak Bilgisi Öğretmenlerinin Kendi Algılarına Dayalı Sını Yönetimi Yeterlikleri (Konak İlçesi Örneği). İzmir: Dokuz Eylül Üniversitesi, Sosyal Bilimler Enstitüsü, Yüksek Lisans Tezi, 2007.

Kiriş, Hacı Mustafa. “Diyanet İşleri Başkanlığı Personel Yeterlikleri Bağlamında İlahiyat Fakültesi Lisans Programlarının İşlevselliği". Cumhuriyet Üniversitesi Edebiyat Fakültesi Sosyal Bilimler Dergisi 42/2 (2018), 47-76.

Koç, Ahmet. “Din Kültürü ve Ahlâk Bilgisi Öğretmenlerinin Yeterlikleri”. Değerler Ĕ̆itimi Dergisi 8/19 (Haziran 2010), 107-149.

Koç, Ahmet. “İmam Hatip Lisesi Meslek Dersleri Öğretmenlerinin Yeterlikleri Üzerine Bir Araştırma". C.Ü. İlahiyat Fakültesi Dergisi 13/2 (2009), 131-174.

Köylü, Mustafa. “Türkiye'de Yüksek Din Öğretimi: Nicelik miNitelik mi?”. Ondokuz Mayıs Üniversitesi İlahiyat Fakültesi Dergisi 35 (2013), 21-44.

MEB, Millî Eğitim Bakanlığ Ö Ŏretmen Yetiştirme ve Geliştirme Genel Müdürlüğünün 43501582-774.01.01-E.5586019 Sayı ve 16.03.2018 Tarihli Yazısı. Erişim 28 Kasım 2019. http://urgupihl.meb.k12.tr/meb_iys_dosyalar/50/08/748839/ dosyalar/2018_03/27111647_YYretmenlik_UygulamasY_DanYYmanlYY. pdf.

MEB, Millî Eğitim Bakanlığı Öğretmen Yetiştirme ve Geliştirme Genel Müdürlüğünün 31666252-399-E.13465016 Sayı ve 11.09.2017 Tarihli Yazısı. Erişim: 28 Kasım 2019.https://oygm.meb.gov.tr/meb_iys_dosyalar/2017_12/06164534y yyretmenlik_uygulamasy.pdf.

Nazıroğlu, Bayramali. “İlahiyat Fakültelerinde Din Eğitimi ve Sorunları”. Türkiye'de Din Ĕgitimi ve Sorunları. ed. Mustafa Köylü. 169-209. İstanbul: Dem Yayınları, 2018.

Okutan, Mehmet. “Disiplin Problemlerinin Sürekliliği”. Sınıf Yönetimi. ed. Emin Karip. 1-9. Ankara: Pegem Akademi, 14. Basım, 2017.

Öcal, Mustafa. Osmanlı'dan Günümüze Türkiye'de Din Eğitimi. İstanbul: Dergâh Yayınları, 2. Basım, 2017.

ÖYGM, Öğretmen Yetiştirme ve Geliştirme Genel Müdürlüğü. “Öğretmenlik Uygulaması Danışmanlığı Eğitici Eğitimi Kursu” (14 Mart 2019). Erişim 28 
Kasım 2019. https://oygm.meb.gov.tr/www/ogretmenlik-uygulamasi-danismanligi-egitici-egitimi-kursu/icerik/718.

ÖYGM, Öğretmen Yetiştirme ve Geliştirme Genel Müdürlüğü. “Öğretmenlik Uygulaması Danışmanlığı Eğitici Eğitimi Kursu" (12 Şubat 2019), Erişim 28 Kasım 2019. http://oygm.meb.gov.tr/www/ogretmenlik-uygulamasi-danismanligi-egitici-egitimi-kursu/icerik/714.

ÖYGM, Öğretmen Yetiştirme ve Geliştirme Genel Müdürlüğü. “Din Kültürü ve Ahlak Bilgisi Öğretmeni Özel Alan Yeterlikleri”. Erişim 24 Ocak 2020. http:// oygm.meb.gov.tr/meb_iys_dosyalar/2017_11/06160735_12-YYretmen_Yeterlikleri_KitabY_din_kYltYrY_ve_ahlak_bilgisi_YYretmeni_Yzel_alan_yeterlikleri_ilkYYretim_parYa_15.pdf.

ÖYGM, Öğretmen Yetiştirme ve Geliştirme Genel Müdürlüğü. “Öğretmenlik Mesleği Genel Yeterlikleri”. Erişim 27 Kasım 2019. http://oygm.meb.gov. tr/meb_iys_dosyalar/2017_12/11115355_yyretmenlyk_mesleyy_genel_yeterlyklery.pdf.

PFESPIÇUE, Pedagojik Formasyon Eğitimi Sertifika Programına İlişkin Çerçeve Usul ve Esaslar. Türkiye: Yükseköğretim Kurulu, 2015. Erişim 23 Ekim 2019. https://Www.Yok.Gov.Tr/Sayfalar/Kurumsal/Idaribirimler/Egitim@ Ogretim_Daire_Bsk/Pedagojik-Formasyon-Usul-Ve-Esaslar.Aspx.

Sünkür, Meltem vd. "Akıllı Tahta Uygulamaları Konusunda İlköğretim II. Kademe Öğrencilerinin Görüşleri (Malatya İli Örneği)". E-Journal Of New World Sciences Academy 7/1 (2012), 313-321. Erişim 5 Şubat 2020. https://dergipark. org.tr/en/download/article-file/185493.

Süral, Serhat - Sarıtaş, Emel. "Pedagojik Formasyon Programına Katılan Öğrencilerin Öğretmenlik Mesleğine Yönelik Yeterliklerinin İncelenmesi”. Mersin Üniversitesi Ĕ̆itim Fakültesi Dergisi 11/1 (Nisan 2015), 62-75.

Şaşmaz Ören, Fatma vd. “Öğretmen Adaylarının Okul Deneyimi Derslerine Yönelik Tutumlarının ve Görüşlerinin Değerlendirilmesi". Kuram ve Uygulamada Ĕ̆itim Yönetimi 15/58 (2009), 217-246.

Şimşek, Eyüp. “Din Kültürü ve Ahlak Bilgisi Dersi Öğretmenlerinin Öğretim Teknolojileri Alanındaki Yeterlikleri”. Atatürk Üniversitesi Sosyal Bilimler Enstitüsü Dergisi 22/3 (Eylül 2018), 1631-1648.

Tuncer, Murat -Berkant, Hasan Güner. “Öğretmen Yetiştirme Programlarının Özellikleri”, Öğretmen Yetiştirme Sistemimiz, ed. Mustafa Ergün vd. 93-127 Ankara: Pegem Akademi, 2018.

Turan, İbrahim. “Türkiye'de İlahiyat Eğitimi: İstihdam Alanı-Program İlişkisi 
Üzerine BirDeğerlendirme". İstanbul ÜniversitesiIlahiyat Fakültesi Dergisi 37 (Aralık 2017), 59-77.

Turan, İbrahim. “Öğretmen Eğitimi ve Bilişim Teknolojileri”. Aday Öğretmenler İçin Okul Deneyimi ve Öğretmenlik Uygulaması, ed. İsmail Hakkı Demircioğlu. 197-215. Ankara: Anı Yayıncılık, 3. Basım, 2015.

UÖMEBBEÖKYÖYİY, Uygulama Öğrencilerinin Millî Eğitim Bakanlığına Bağlı Eğitim Öğretim Kurumlarında Yapacakları Öğretmenlik Uygulamasına İlişkin Yönerge. Türkiye: Öğretmen Yetiştirme ve Geliştirme Genel Müdürlüğü (2018). Erişim 24 Ocak 2020. https://oygm.meb.gov.tr/meb_iys_dosyalar/2018_06/25172143_YYnerge.pdf.

Yazıc1, Iş1l. İlköğretim Din Kültürü ve Ahlak Bilgisi Öğretmenleri Yeterlikleri (İstanbul İli Örneği Üzerinde Bir Alan Araştırması). Ankara: Ankara Üniversitesi, Sosyal Bilimler Enstitüsü, Yüksek Lisans Tezi, 2004.

Yeğin, Hüseyin İbrahim. “Din Kültürü ve Ahlâk Bilgisi Öğretmenlerinin Tükenmişlik Düzeyleri”. Ekev Akademi Dergisi 58 (Kış 2014), 315-332.

Yıldız, Muhammet Mesut. Din Kültürü ve Ahlak Bilgisi Öğretmenlerinin Kendi Algllarına Göre Sını Yönetimi Becerileri. Erzurum: Atatürk Üniversitesi, Eğitim Bilimleri Enstitüsü, Yüksek Lisans Tezi, 2019.

Yorulmaz, Bilal. “Din Kültürü ve Ahlak Bilgisi Öğretmenlerinin Seçmeli Kur'an-1 Kerim, Hz. Muhammed'in Hayatı ve Temel Dini Bilgiler Derslerine İlişkin Öz Algıları". Marmara Üniversitesi Öneri Dergisi 11/41 (2014), 301-324.

Zengin, Mahmut. “Din Kültürü ve Ahlak Bilgisi Öğretmenlerinin Eğitim Öğretim Yeterlik Algıları”. Sakarya Üniversitesi İlahiyat Fakültesi Dergisi 15/27 (2013), $1-28$. 